\title{
Exploring Entrepreneurial Skills and Competencies in Farm Tourism
}

*Paper prepared for the 'Ninth Rural Entrepreneurship Conference', Nottingham Business School, Nottingham Trent University, $23^{\text {rd }}-24^{\text {th }}$ June 2011.

\section{Chris Phelan}

School of Sport, Tourism \& The Outdoors

University of Central Lancashire

CJPhelan@uclan.ac.uk

Is a PhD student in the School of Sport, Tourism \& The Outdoors, at the University of Central Lancashire, Preston, UK. Investigating farm tourism and the supply of farm based recreation, his project critically appraises the nature and extent of the entrepreneurial competencies, activities and needs of farmers as providers of rural tourism products and experiences. Locating the analysis within contemporary UK and EU rural development and diversification policies.

\section{Richard Sharpley \\ School of Sport, Tourism \& The Outdoors \\ University of Central Lancashire}

Professor of Tourism and Development at the University of Central Lancashire, Preston, UK. He has previously held positions at a number of other institutions, including the University of Northumbria (Reader in Tourism) and the University of Lincoln, where he was professor of Tourism and Head of Department, Tourism and Recreation Management. His principal research interests are within the fields of tourism and development, island tourism, rural tourism and the sociology of tourism. He has published numerous journal articles on these subjects and his books include Tourism and Development in the Developing World (2008), Tourism, Tourists and Society, 4th Edition (2008) and Tourism, Development and Environment: Beyond Sustainability (2009). 


\title{
Exploring Entrepreneurial Skills and Competencies in Farm Tourism
}

\begin{abstract}
Diversification to farm tourism is increasingly seen as a viable development strategy to promote a more diverse and sustainable rural economy and to counter declining farm incomes. However, our understanding of the dynamics of the modern farm tourism business and the entrepreneurial and competitive skills farmers require in making the transition from agriculture to a diversified - and service based - enterprise remains limited. Hence, the aim of this paper is to explore the range of skills and competencies that farmers in the North West of England identify as important when adopting a diversification strategy to farm tourism. With the findings indicating that that whilst a range of managerial skills are valued by farmers, they lack many of the additional business and entrepreneurial competencies required for success. Moreover, this paper acknowledges the need to generate consensus on the requisite skill-set that farm tourism operators require, along with a need for a currently fragmented rural tourism literature to acknowledge the significance of rural entrepreneurship and the characteristics of successful farmers and farm tourism ventures.
\end{abstract}

\section{Introduction}

Farm based recreation and tourism is acknowledged as one of a number of potential strategies for farm families who, in the context of declining farm incomings and reforms to the European Union's (EU) Common Agricultural Policy (CAP) wish to remain 'on the land'. This paper outlines the findings from an empirical investigation, which considers the range of skills and competencies that farmers in the North West of England identify as important for successful diversification to farm tourism. Although the context of this research is diversification to tourism in the UK, the subject is one that applies to many farm households in the developed nations of the world, where the promotion of tourism as an alternative farm enterprise has become a significant development strategy within rural and peripheral regions (Hjalager, 1996; Jones, et al., 2009; Ollenburg, 2008).

The overriding trend in UK farming has been that 'total income from farming' has declined steadily over recent decades, from $£ 8.9 \mathrm{~m}$ in 1973 to $£ 4.4 \mathrm{~m}$ in 2010 (Defra, 2010). Moreover, these declining farm incomes and ongoing CAP reform have led to increasing pressures for a reorientation from productivist to more entrepreneurial models of farming, with the result that farmers are increasingly required to become more market oriented, and to treat their 'farms as firms', in order to survive (Meert, et al., 2005; Phillipson, et al., 2004; Jones, et $a l ., 2009)$. Thus, as diversification becomes an almost expected agricultural practice, farmers are 
increasingly recognised as entrepreneurial, needing to develop new skills and capabilities to remain competitive (McElwee, 2006); as Smit (2004) argues, entrepreneurship is increasingly becoming the most important aspect of modern farming. Indeed, the UK government's own definition alludes to this, describing diversification as, 'the entrepreneurial use of farm resources, for a non-agricultural purpose, for commercial gain' (Defra, 2009:14).

Consequently, a growing literature is now emerging on rural entrepreneurship and, in particular, on the role of business enterprise characteristics and the range of skills deemed critical to the success of farm ventures (see Clark, 2009; Couzy and Dockes, 2008; Hildenbrand and Hennon, 2008; McElwee, 2006; McElwee, 2008; McElwee and Bosworth, 2010; Vesala and Vesala, 2010; Wolf, et al., 2007). Not surprisingly, many of these skills reflect those more generally proposed in the entrepreneurship literature. For example, McElwee (2008) suggests that networking, innovation, risk taking, team working, reflection, leadership and business monitoring are fundamental to developing and improving the farm business. Equally, Morgan, et al. (2010) emphasise what they describe as higher order skills, namely: creating and evaluating a business strategy; networking and utilising contacts; and, recognising and realising opportunities. Elsewhere, it has been proposed that farming and diversification require different skills (Pyysiäinen, et al., 2006); as McElwee (2008:465) notes, 'farmers are business people in that they run businesses but in practice they do not necessarily have well defined business skills.'

In the UK, this view is confirmed by Defra (2007), who acknowledge that one of the key issues that inhibits a farmer's decision to diversify, or indeed threatens the success of any diversified project undertaken, is a lack of 'business skill'. This is manifested in the apparent difficulties UK farmers have in identifying market opportunities, uncertainty about the direction in which to take their business, an inability to develop a long term business plan, and a reluctance to take an investment risk (NAO, 2004). However, whilst Defra has evidence of specific business skills gaps, the extent to which they currently exist is not clear and warrants further research (Hill, 2007). As Defra outlines,

'Competence in business skills is key both to successful start-up of diversified businesses and ongoing profitability. These skills also impact positively on the planning and management of the mainstream agricultural enterprises so that their acquisition provides a double benefit. Few farmers can now rely solely on their knowledge of basic commodity production. Many have already diversified or added value to produce, and need the skills required to run new businesses, including dealing directly with customers, marketing their products, and selecting and managing staff,' (2007:8). 
Whilst the increased attention on farmers as entrepreneurs and on the necessary entrepreneurial and managerial skill set amongst diversified farm ventures is welcomed, the skills and characteristics outlined above relate to farm diversification generally. As a result, such skills have yet to be fully explored in the context of diversification to service-based farm tourism in particular and, consequently, their consideration in the tourism literature is conspicuous by its absence. Indeed, Busby and Rendle (2000) highlight the absence of studies that discuss the role of entrepreneurship within the dynamics of the modern farm tourism business, although this is, perhaps, unsurprising given the distinct lack of attention paid to theories of entrepreneurship within tourism scholarship generally ( $\mathrm{Li}, 2008$ ), the entrepreneur being described as 'the overlooked player in tourism development' (Koh and Hatten, 2002).

However, whilst the farm tourism literature remains fragmented and somewhat limited, a number of studies have begun to explore the characteristics and profile of farm tourism operators, albeit usually as subsidiary findings within larger studies associated with farm tourism motivations. Often, these findings focus on the transferability of existing skills and knowledge in operating a farms core operation, the implication being that the any management skills acquired here provide the foundation for operating a successful tourism enterprise. For instance, Butts, McGeorge and Briedenhann (2005), discussing a successful 'Maize Maze' attraction in Devon, argue that the basic business principles the farm family had established from their core farming operation readily formed the basis for their later successful diversification. Conversely, others argue that different skill sets when diversifying from agriculture are needed (Pyysiäinen, et al., 2006).

Elsewhere, the discussion centres on the absence of specific competencies, with business planning and marketing skills frequently cited as deficient amongst farm tourism ventures (McGehee, 2007; Sharpley and Vass, 2006; Wilson, 2007) whilst, more generally, it is accepted that diversification to farm based recreation does require mastery of a new set of skills. The challenge facing farmers is succinctly articulated by Getz, Carlsen and Morrison (2004: 125) who observe that 'farming is supply-driven, tourism is market-led; farmers are cost-cutters, tourism businesses are revenue maximisers; farmers produce single standardised products at a given price, tourism businesses diversify into many products and offer a range of prices'.

Thus, it is evident that, despite contemporary policy directed at incentivising farm 
diversification to tourism and the prevailing view amongst many farmers as to its suitability, there is little consensus on the range of entrepreneurial and management skills that farmers require or, indeed, if these skills differ from those required in other non-service based diversification ventures or in agricultural management more generally. This suggests a theoretical weakness within tourism discourse, with subsequent implications for rural areas and farm households alike. Therefore, the following sections will briefly review the entrepreneurial skills and competencies identified in the literature as essential to venture success before identifying the skills, revealed in the research, that farmer in the North West of England identify as important for successful diversification to tourism enterprise.

\section{Introducing Entrepreneurial Skills and Competencies}

As outlined above, entrepreneurs require a variety of skills in order to successfully manage an enterprise. Wickham, (2006:100) defines skill as 'simply knowledge which is demonstrated by action', before going on to add that 'entrepreneurial performance results from a combination of industry knowledge, general managements skills and personal motivation'. Rae (2007) concurs that both an entrepreneurial and managerial skill-set are required to run a successful venture and conceptualises these as 'entrepreneurial management capabilities'. This capabilities approach extends the list of skills already cited, to include: leading and managing people, managing finances, personal organisation, innovation, strategic planning and investigating opportunity. However, in contrast to skills and capabilities, the 'competency approach' has emerged as an increasingly popular means of studying entrepreneurial characteristics. Man et al., (2002:133) describe competencies as 'higher level characteristics, representing the ability of the entrepreneur to perform a job role successfully'. Therefore, both entrepreneurial skills and entrepreneurial competencies represent appropriate frameworks for the subsequent research amongst farmers who have diversified to tourism in the study area.

\section{Establishing an Entrepreneurial Skills-Set}

Lazear $(2004 ; 2005)$ maintains that an entrepreneur is not necessarily required to be an expert in any single skill but, instead, is required to be a jack-of-all-trades (JAT). He argues that, in order to be successful, one must be 'sufficiently skilled in a variety of areas to put together the many ingredients required to create a successful business' (Lazear, 2005: 676). Moreover, the JAT 
view of entrepreneurship is supported by Wagner (2003; 2006) and Asteboro and Thompson (2011) who suggest that having a balanced skills mix stimulates entrepreneurship. In contrast, Silva (2007) proposes a more cautious interpretation of the JAT approach, having found in a longitudinal study of Italian entrepreneurs that acquiring a wider skill set was not significant. Here, Silva speculates that would-be entrepreneurs purposefully invest in an intentionally broad skills mix which, in turn, increases the likelihood of running a business. Although Asteboro and Thompson (2011) are more broadly in favour of the JAT approach, they do extend their argument and propose that those with a greater taste for variety are more likely to become entrepreneurs, suggesting that a more varied education and employment history and, thus, skillset is a likely expression of this taste. These later considerations aside, the implication of the JAT approach to entrepreneurship is that those with a broad and balanced skill set are more likely to become entrepreneurs. Moreover, Lazear (2004) proposes that if a nascent entrepreneur does not possess a complete skill set, then any additional skills can be acquired.

The idea that skills can be acquired also underpins the work of Lichtenstein and Lyons (2001) who developed a skills based framework termed the 'Entrepreneurial Development System' (EDS). The EDS framework has been applied to rural areas of the United States to establish both the quantity and quality of an areas entrepreneurial capital and is based on three main premises: (1) ultimate success in entrepreneurship requires the mastery of a set of skills; (2) these skills can be developed; and (3) entrepreneurs do not all come to entrepreneurship at the same skill level (see also: Lyons, 2003). This system has also been utilised by Smith, Schallenkamp and Eicholz (2007), who present the skills framework under the headings of technical, managerial, entrepreneurial skills and personal maturity skills. Under the EDS approach, respondents are asked to rank the skills they consider most useful in their practice as well as perform a self-evaluation of their own ability against each of the entrepreneurial skills presented. The self-assessment allows facilitators to gauge the level of entrepreneurial capital present and to establish whether this can be enhanced or maximised over time, following peersupport and entrepreneurial development education, amongst other interventions.

Rather than allowing respondents to self-evaluate, Chell (2008) employs a list of skills as practical indicators for judging the existence of entrepreneurial behaviour through textual analysis of a series of entrepreneurial cases. Whilst acknowledging that the individual constructs being assessed are 'complex and multifaceted', Chell identifies the expert term 'alertness' as the 
indicator of the ability to recognise an opportunity as an entrepreneurial behaviour. Conversely, 'leadership' demotes the ability to manage other people, whilst 'social' and 'strategic' competence indicate networking and the ability to grow and sustain an enterprise. Chell identifies and scores these 'behaviours' and 'expert terms' and, whilst acknowledging that some may find the approach subjective, she suggests that the expert terms (see Table 1 below), which elsewhere would be labelled simply as skills, 'are being used as tools to indicate the form of life rather than an inherent trait within the individual' (2008: 214). Thus, the selection and identification of appropriate entrepreneurial skills as criteria, expert terms or markers would seem to hold some practical value for the study of entrepreneurship.

Table 1: Practical criterion for judging the existence of entrepreneurial behaviour (Source: Chell, 2008:211)

\begin{tabular}{|c|c|c|c|}
\hline Creativity & Resourcefulness & Judgment & Resilience \\
\hline Alertness & Persuasiveness & Risk Propensity & Flexible \\
\hline $\begin{array}{c}\text { Perception And } \\
\text { Interpretation }\end{array}$ & Self Efficacy & Social Competence & Manipulative \\
\hline Business Acumen & Self-Confidence & Political Astuteness & Stamina \\
\hline $\begin{array}{c}\text { Social / Market } \\
\text { Awareness }\end{array}$ & Leadership & Adeptness & Strategic Competence \\
\hline
\end{tabular}

\section{Conceptualising Entrepreneurial Competencies}

Aligned to the use of the terms entrepreneurial skills or entrepreneurial capabilities outlined above, a growing body of literature emphasises the role of entrepreneurial competencies (Bird, 1995; Man, 2006; Man, et al., 2002; Mitchelmore and Rowley, 2010). The competence-based approach is one that has been popularised in the field of human resource development along with the vocational education and training literatures. Yet, despite this, there remains considerable confusion surrounding the term and as such it has been labelled a 'fuzzy concept', not least because, for some, competencies are the equivalent to skills and knowledge (Hayton and McEvoy, 2006) whilst others describe competence as the modern terminology for ability (Bridge, et al., 2009). Certainly, two key uses of the term competency exist, firstly, competency as the behaviour one demonstrates and, secondly, competency as minimum performance standard (Mitchelmore and Rowley, 2010). 
Following a review of the meanings associated with the term, Le Deist and Winterton (2005) propose a typology of competence (see Figure 1 below). For them, the areas of 'knowledge and understanding' are captured by the heading of cognitive competence, 'skills' are considered functional competencies, and 'behavioural and attitudinal competencies' are inclusive in what they term social competence. Within the typology, meta-competence is a fourth and more complex dimension, in that it is concerned with 'facilitating the acquisition of the other substantive competencies' (2005: 39).

Figure 1: A typology of competence (Source: Le Deist and Winterton, 2005:39).

\begin{tabular}{lc|c} 
& \multicolumn{1}{c}{ Occupational } & Personal \\
Conceptual & $\begin{array}{c}\text { Cognitive } \\
\text { Competence }\end{array}$ & $\begin{array}{c}\text { Meta } \\
\text { Competence }\end{array}$ \\
\cline { 2 - 3 } & $\begin{array}{c}\text { Functional } \\
\text { Operational }\end{array}$ & $\begin{array}{c}\text { Social } \\
\text { Competence }\end{array}$
\end{tabular}

Brinckmann (2007) makes the case for borrowing from the management competence literature when exploring entrepreneurship, proposing that competence consists of three fundamental domains, namely: functional, social, and conceptual. In so doing, Brinckmann adapts and expands the management competence framework to retain the social and functional components with the addition of a third 'general entrepreneurial competence' domain which incorporates the earlier cited 'conceptual competence' (See Figure 2).

Moreover, Brinckmann (2007) acknowledges that the competency approach remains relatively underdeveloped within the entrepreneurship literature but can be distinguished from the traits approach (Kobia and Sikalieh, 2010). Whilst the traits approach concerns attitudes or pre-dispositions, a competency based approach takes a broader perspective in investigating competencies as antecedents to venture success. 
Figure 2. Entrepreneurial Management-Competence Domains (Source: Brinckmann, 2007)
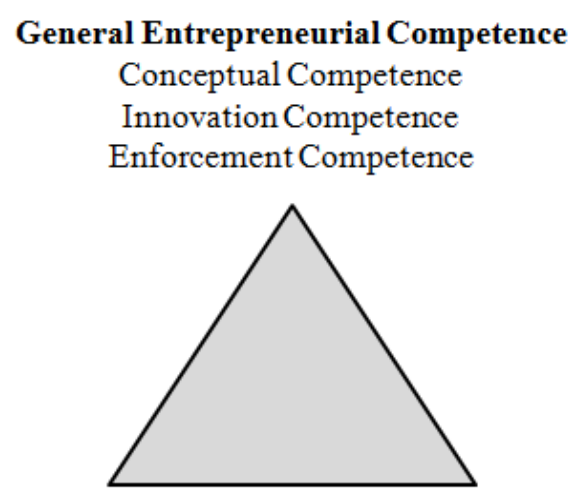

$\begin{array}{cc}\text { Social Competence } & \text { Functional Competence } \\ \text { Teamwork Competence } & \text { Technology Management Competence } \\ \text { Leadership Competence } & \text { Marketing Management Competence } \\ \text { NetworkCompetence } & \text { Financial Management Competence }\end{array}$

Researchers at Wageningen University have used a self- assessment approach to assess the entrepreneurial competency of owner-managers in the horticulture and agrifood sectors of Belgium and the Netherlands (Lans, et al., 2010; Lans, et al., 2008; Mulder, et al., 2007). Amongst the 21 competencies they identify, 'self-management' and 'learning orientation' are identified as the two highest scoring, with 'opportunities', 'international orientation' and 'human resource management' as the lowest (see Table 2). Subsequent assessment of the ownermanager's competence was also sought from colleagues within the firm's management structure, as well as from consultants and advisors associated with the business. Analysis of these later assessments reveals that, in the majority of instances, the owner-manager has rated their own mastery of entrepreneurial competencies significantly lower than these third party assessors have.

What is also clear is that many of the competencies from the Wageningen research are recognisable from the entrepreneurship and HRD literatures and the earlier discussions above. Additionally, the Wageningen studies conclude that the true potential of focusing on entrepreneurial competence lies in making the small-business owner aware of his / her own competence level, identifying the importance of specific competencies to business success, and in providing direction and guidance in competence and skill development (Lans, et al., 2008). 
Thus, for these authors, identifying and measuring specific entrepreneurial competencies holds real value for the study of entrepreneurial learning and leads the authors to call for greater research on this subject in comparable, well-defined small-business sectors (Lans, et al., 2010).

Table 2: Entrepreneurial competencies amongst small business owners in the horticulture and agrifood sector (Source: Mulder, et al. (2007); Lans, et al. (2010)).

\begin{tabular}{|c|c|c|}
\hline Learning Orientation & Problem Analysis & Management Control \\
\hline Self Management & Organising & Value Clarification \\
\hline Planning & Conceptual Thinking & Judgement \\
\hline Market Orientation & Negotiating & Team Work \\
\hline Result Orientation & Persuasiveness & Strategic Orientation \\
\hline Networking & Vision & HRM / HRD \\
\hline Leadership & General Awareness & International Orientation \\
\hline
\end{tabular}

Bergevoet (2005), using data from Dutch dairy farmers, explores craftsmen, managerial and entrepreneurial competencies in relation to psychological variables and venture success. Bergevoet's work utilises many of the skills and competency areas previously highlighted, including opportunity, strategic, conceptual, organising and relationship competencies, and finds a positive relationship between higher scores in these competency areas and entrepreneurial venture success. However, it must be noted that respondents were asked to self-report against their own entrepreneurial success, thereby introducing a subjective element of to the process. Later work by Bergevoet (2005; 2006) with extension and agricultural training programs, identifies that entrepreneurial competencies can be enhanced through farmer led study groups, thus highlighting the potential for competency evaluation as a basis for agricultural extension programmes.

Nuthall (2006) investigates the relative importance of various management competencies amongst family farm businesses in New Zealand. Determining that, whilst a relatively broad range of skills are deemed important, these were largely common to all farm types, age groups and educational backgrounds, with variations in farm objectives not influencing the ranking of the skills. Along with skills related to primary production - as one would expect from a study of farm management - were statements related to managerial style and entrepreneurial skills, with 
information seeking, forecasting and an ability to negotiate ranking highly alongside other entrepreneurial skills including recognising opportunities, control belief and risk factors (see also, Nuthall, 2010).

Many of the competencies highlighted above emerge from the work of Man, Lau and Chan (2002) who have developed a model of entrepreneurial competency that attempts to cluster or categorise competency areas, including opportunity, relationship, conceptual, organising, strategic and commitment competencies. In a similar vein, later work by Mitchelmore and Rowley (2010) proposes an entrepreneurial competency model that maintains a distinction between 'entrepreneurial' and 'business and management' competencies, along with additional clusters for 'human relations' and 'conceptual and relationship' competencies. The competency frameworks of Man, Lau and Chan (2002) as well Mitchelmore and Rowley (2010) are based on extensive reviews of the entrepreneurship literature by the respective authors and, along with the earlier discussion regarding the categorisation of entrepreneurial skills (and the EDS approach of Schallenkamp and Smith, 2008) are presented together in Table 3 below.

Whilst any attempt at a direct comparison between the three competence / skills taxonomies remains problematic, the framework in Table 3 attempts to align these clusters to highlight shared themes and, in so doing, also presents the associated underlying skills and functional competencies associated with these clusters. However, as Luken (2004) cautions, just as the definition of competence is not homogeneous, any attempt at competence assessment remains subjective and should ideally take account of the context as well as the individual they are applied to. Furthermore, as Bird (1995) also notes, whilst some entrepreneurial competencies have been empirically supported, others remain at best theoretical and speculative. An additional limitation of the competency approach is that it is not definitive, with Bridge, et al., (2009) highlighting that there are few competencies possessed by all entrepreneurs - just as some are possessed by non-entrepreneurs. Nevertheless, the clusters and their underlying skills in Table 3 provide a useful tool to support the research that now follows. 
Table 3: Aligning competence clusters and their underlying skills

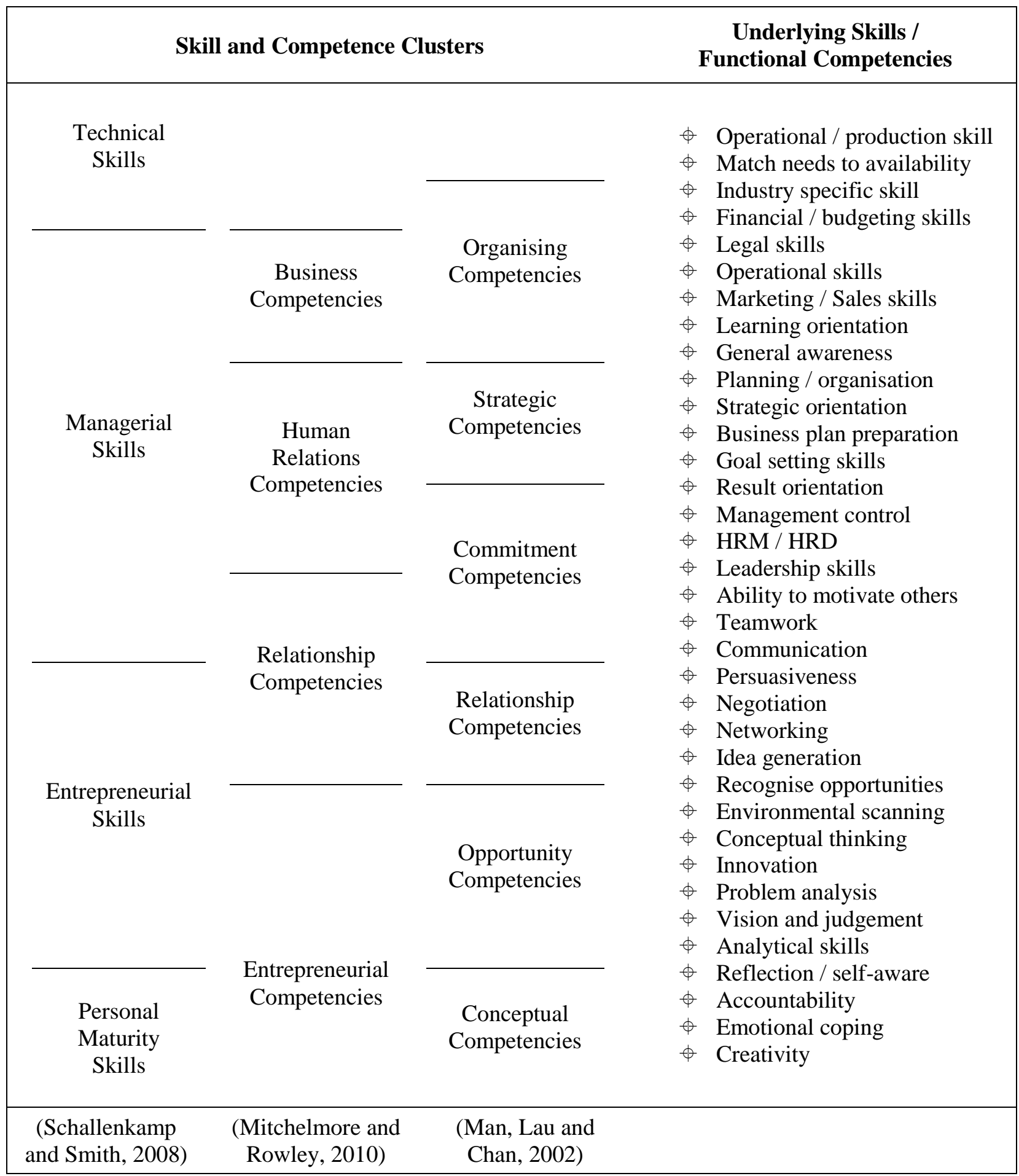




\section{The Research: Skills and Competencies for farm Tourism}

Having reviewed the clustering of skills as outlined in the framework in Table 3, an exploratory study was undertaken to explore the range of skills and competencies that farmers in the North West of England identify as important for successful diversification to farm tourism enterprise. This exploratory study took the form of a postal questionnaire, drawing on the 'Entrepreneurial Development System' work of Smith, Schallenkamp and Eicholz (2007) outlined above. Following the review of skills and competencies, it proved necessary for the researchers to identify a smaller - more salient - set of the most critical skills to present to respondents. Additionally, for the purposes of this study the selection needed to acknowledge the competencies considered most relevant to the rural, land-based and tourism and hospitality service industries, as identified by the UK Sector Skills agencies for these industries (Lantra, 2005; People1st, 2007). In so doing, it must be accepted that some bias may have entered the final skills selection although to counter this, the selection (Table 4) was pre-tested with farmers and those in farm tourism and business support roles, such as with the regional tourist boards for the North West. The self-completion questionnaires were mailed to 387 farm tourism enterprises in the region, with 118 fully completed questionnaires returned, representing a response rate of 30 percent. As well as answering preliminary questions regarding the farm and tourism venture, the respondents were asked to rate the importance of the fifteen selected skills, from (1) unimportant through to (5) very important, and subsequently asked to self-assess their own abilities against the skills and competencies cited as either (1) low, (2) medium or (3) high.

\section{Farmers' Perception of the Desired Skills and Competencies}

The mean rankings against each of the skills deemed most applicable by the farmers sampled are shown in Table 4 and range from a high of 4.52 for customer service to 2.98 for the supervision and management of employees. The skills and competencies have been grouped into business and managerial skills, along with entrepreneurial and personal maturity skills, to allow for ease of analysis. 


\begin{tabular}{|lll|}
\hline $\begin{array}{l}\text { Table 4. Farmers perception of the importance of selected 'skills and competencies } \\
\text { for farm tourism enterprise' }\end{array}$ & & \\
\hline & $\mathrm{M}$ & $\mathrm{SD}$ \\
Business \& Management Skills / Competencies & 4.52 & 0.88 \\
Customer Service: Handling service expectations and dealing with problems & 4.28 & 0.95 \\
Financial: Managing financial resources, accounting, budgeting & 4.14 & 1.02 \\
Marketing/Sales: Identifying and reaching customers/distribution channels & 4.13 & 0.97 \\
Organisational Skills: Day to day administration, managing yourself and your time & 3.95 & 1.16 \\
Small Business Regulations: . i.e. H\&S, risk assessment, disability legislation & 2.98 & 1.59 \\
Supervision: Manage/supervise employees and their needs & & \\
& & \\
Entrepreneurial \& Personal Maturity Skills / Competencies & 4.39 & 0.81 \\
Accountability: Ability to take responsibility for solving a problem & 4.31 & 0.89 \\
Emotional Coping: Emotional ability to cope with a problem & 3.91 & 1.09 \\
Critical Evaluation: The ability to think critically & 3.81 & 1.14 \\
Networking: Co-operation with others, networking and utilising contacts & 3.75 & 1.14 \\
Self Awareness: Ability to reflect and be introspective & 3.68 & 1.16 \\
Environmental Scanning: Recognise market gap, exploit market opportunity & 3.66 & 1.13 \\
Business Concept: Business and strategic planning & 3.64 & 1.14 \\
Goal Setting: Ability to set personal goals, reach them and set new ones & 3.58 & 1.12 \\
Negotiation: Persuasive communication and negotiation skills & & \\
&
\end{tabular}

With respect to business and management competencies, 'customer service' skills are clearly identified by the respondents as being the most important attribute, with a mean ranking of 4.52 and a standard deviation of 0.86 . Indeed, 23.7 percent of respondents categorise service skills as important and 67.8 percent as very important in managing their farm tourism ventures. Additionally, high mean values were recorded for 'financial' (4.28), 'marketing and sales' (4.14) and 'organisation skills' (4.13). Of slightly less significance to respondents was the fifth ranked business and management variable of 'small business regulations' (3.95). This may be considered more of a knowledge competency than an actual skill and was included in the final skills selection, given its prominence in the policy literature for both farming and leisure enterprises generally (see: Defra, 2007; Lantra, 2005; People1st, 2007). Of least importance was the supervision and management of employees (2.98) although, as many of the farms surveyed are family farms, the anticipated roles of recruitment, training and appraisal were unlikely to be deemed relevant by respondents. 
Amongst the remaining skills and competencies, considered entrepreneurial - or conceptualised as higher order or personal maturity skills and competencies - 'accountability' and 'emotional coping' are ranked highly at 4.39 and 4.31. The remaining entrepreneurial and higher order skills, from the ability to 'think critically' to 'persuasive negotiation skills,' are ranked from 3.91 to 3.58 , suggesting that they remain of importance in diversifying from the farmers perspective, but less so than a number of the management skills acknowledged above. Within this selection, it is important to note that two competencies frequently associated with entrepreneurship - namely 'environmental scanning' (elsewhere termed opportunity recognition) and 'business concept' (or planning) - are revealing. Both have very similar mean values (3.68 and 3.66) though wide distributions. Indeed, closer analysis identifies that 38.1 per cent of those surveyed rated 'environmental scanning in the categories unimportant through to moderately important, whilst 37.3 per cent rated 'business concept' in the same unimportant to midimportance range. Taken at face value, this indicates that, for a number of farm businesses, entrepreneurial competencies are not deemed to be as significant as those management - or functional competencies - identified.

\section{Farmer's Personal Skills and Competency Evaluation}

In the follow up section of the questionnaire, farmers were asked to rate their own abilities against each of the 15 competencies selected as either (1) low, (2) medium or (3) high. The results of this analysis are presented in Table 5, whilst the skills that respondents evaluated as both the lowest and highest abilities are presented in Tables 6 and 7 .

With regards to the skills in which the respondents considered themselves proficient, 'customer service' emerges as the strongest, with a mean ranking of 2.69. Moreover, 72.9 percent of farmers surveyed identified that they had a high 'customer service' ability and only 3.4 percent considered scoring themselves low in their self-assessment. This is followed closely by 'accountability', 'critical evaluation' and 'emotional coping', which are again reflected by a very high number of respondents ranking themselves with high ability (mean scores of 2.54 to 2.65). Given the earlier results which indicated that farmers considered these competencies as essential, the relatively high scoring of these 'higher order' and 'personal maturity skills' is encouraging. However, 'financial' and 'marketing' skills, previously identified as important for successful diversification, ranked quite low in the self-assessment exercise. More specifically, 
marketing, which farmers earlier highlighted as an important management competency, is selfassessed as a high level competency by only 33.9 percent of those surveyed.

\begin{tabular}{|lll|}
\hline Table 5. Farmers self- assessment: Mean rankings & & \\
\hline & $\mathrm{M}$ & $\mathrm{SD}$ \\
Customer Service: Handling service expectations and dealing with problems & 2.69 & 0.53 \\
Accountability: Ability to take responsibility for solving a problem & 2.65 & 0.54 \\
Critical Evaluation: The ability to think critically & 2.62 & 0.73 \\
Emotional Coping: Emotional ability to cope with a problem & 2.54 & 0.63 \\
Organisational Skills: Day to day administration, managing yourself and your time & 2.47 & 0.64 \\
Financial: Managing financial resources, accounting, budgeting & 2.31 & 0.60 \\
Goal Setting: Ability to set personal goals, reach them and set new ones & 2.31 & 0.69 \\
Marketing/Sales: Identifying and reaching customers/distribution channels & 2.19 & 0.68 \\
Networking: Co-operation with others, networking and utilising contacts & 2.19 & 0.74 \\
Self Awareness: Ability to reflect and be introspective & 2.19 & 0.71 \\
Negotiation: Persuasive communication and negotiation skills & 2.14 & 0.67 \\
Business Concept: Business and strategic planning & 2.13 & 0.66 \\
Small Business Regulations: i.e. H\&S, risk assessment, disability legislation & 2.02 & 0.78 \\
Environmental Scanning: Recognise market gap, exploit market opportunity & 2.02 & 0.75 \\
Supervision: Manage/supervise employees and their needs & 1.94 & 0.78 \\
& & \\
\hline
\end{tabular}

\begin{tabular}{|c|c|c|}
\hline \multicolumn{3}{|c|}{$\begin{array}{l}\text { Table 6. Farmers self- assessment: } \\
\text { Skills ranked at 'low' ability }\end{array}$} \\
\hline & $\mathrm{f}$ & $\%$ \\
\hline Supervision & 39 & 33.1 \\
\hline Environmental Scanning & 32 & 27.1 \\
\hline Small Business Regulations & 30 & 25.4 \\
\hline Networking & 23 & 19.5 \\
\hline Self Awareness & 21 & 17.8 \\
\hline Negotiation & 19 & 16.1 \\
\hline Business Concept & 19 & 16.1 \\
\hline Marketing/Sales & 18 & 15.3 \\
\hline Goal Setting & 15 & 12.7 \\
\hline Critical Evaluation & 10 & 8.5 \\
\hline Financial & 9 & 7.6 \\
\hline Emotional Coping & 9 & 7.6 \\
\hline Organisational Skills & 5 & 4.2 \\
\hline Customer Service & 4 & 3.4 \\
\hline Accountability & 4 & 3.4 \\
\hline
\end{tabular}

\begin{tabular}{|lcc|}
\hline $\begin{array}{l}\text { Table 7. Farmers self- assessment: } \\
\text { Skills ranked at 'high' ability }\end{array}$ & \\
\hline & $\mathrm{f}$ & $\%$ \\
Customer Service & 86 & 72.9 \\
Accountability & 81 & 68.6 \\
Emotional Coping & 73 & 61.9 \\
Organisational Skills & 65 & 55.1 \\
Critical Evaluation & 52 & 44.1 \\
Goal Setting & 51 & 43.2 \\
Financial & 46 & 39.0 \\
Networking & 45 & 38.1 \\
Self Awareness & 43 & 36.4 \\
Marketing/Sales & 40 & 33.9 \\
Negotiation & 35 & 29.7 \\
Business Concept & 34 & 28.8 \\
Environmental Scanning & 34 & 28.8 \\
Small Business Regulations & 32 & 27.1 \\
Supervision & 32 & 27.1 \\
& & \\
\hline
\end{tabular}


Of greater interest are those that have previously been identified as entrepreneurial competencies yet which clearly represent very low mean rankings in respect to the respondents' personal skill evaluation. For instance, only 28.8 percent of respondents self-assess as possessing a high personal ability in both 'business concept' and 'environmental scanning' competencies. Moreover, an almost comparable number self-assess as low ability against 'environmental scanning' (27.1 percent), though fewer respondents do so for 'business concept' (16.1 percent).

Thus, it is evident that, by asking farm respondents to self evaluate their own competencies, one can readily identify that a number of managerial and personal maturity skills dominate at the expense of those which are widely identified as entrepreneurial competencies.

\section{Discussion and Conclusions}

What becomes clear from the discussions above is that farmers value a number of managerial competencies, including customer service, managing finances and marketing, as necessary skills for successful diversification. What is also clear is that, when presented with a self-assessment tool, whilst customer service scores highly, competency in finances and marketing rank lower. This suggests that farmers would welcome support in these areas in farm business advisory and support services.

Also prominent within the results is the implication that a range of entrepreneurial and higher order competencies are considered less important, and also self-assessed at a lower competency level, than the earlier cited management functions. Whilst acknowledging that the business and management competencies identified remain important, entrepreneurship is about much more than managing; it is increasingly centred on innovation, risk-taking and the discovery and exploitation of opportunities. Moreover, as opportunity increasingly becomes the foci for entrepreneurship research, then one must acknowledge that 'environmental scanning' (or the ability to recognise and exploit market opportunities) exists only at relatively low levels amongst farm tourism operators in this study area. Similarly, the perception amongst farmers that 'business concept', as a competency, is relatively unimportant for diversification, along with low self-evaluations of their abilities in this regard, raises additional concerns. Consequently, one is forced to question whether the farmers in this research area are entrepreneurial to the extent that the emerging literature on rural enterprise suggests. Evidently, this is an aspect that would require a greater depth of empirical work to confirm, but in the context of the introduction to this 
paper - that farmers must develop new skills and competencies to remain competitive - then the distinct lack of a many of the entrepreneurial competencies identified may have very real implications for the long term survival of these farm tourism ventures

As Lans, et al. (2008) have highlighted, the true potential of focusing on entrepreneurial competence lies in (1) making the small-business owner aware of his / her own competence level, (2) identifying the importance of specific competencies to business success, and (3) providing subsequent direction and guidance in competence and skill development. The nature of the research design here does not allow for progress of this kind, but the contribution of this paper lies in establishing and profiling a specific managerial and entrepreneurial skills-set deemed necessary for farm diversification to tourism. Moreover, future progress lies in establishing a mutually agreed set of competencies and in identifying their significance for entrepreneurial ventures, as a precursor to influencing farm tourism advisory and support systems. Hence, agreement on the specific skills and competence clusters required by both rural entrepreneurs and those engaged in tourism enterprise, is essential and in this respect, the authors welcome critical debate and dialogue on this issue.

Furthermore, this paper establishes that there is clearly greater scope for tourism discourse to engage more deeply with the literature on entrepreneurship and entrepreneurial competence. In particular, the bodies of literature on rural and farm tourism must move beyond the currently limited and fragmented discussion that currently exists on the characteristics of farms and farm families that lead to entrepreneurial success. Indeed, this is a debate overdue in respect to small tourism firms generally, a debate essential, 'to develop a framework unique to the entrepreneurship domain of hospitality and tourism research' (Li, 2008: 1013). Moreover, whilst diversification to tourism remains a prominent strategy, often encouraged by top-down policy initiative and public funding; policies that often identify entrepreneurship as the engine of rural development, then the need to understand and to evaluate the entrepreneurial capital of rural ventures, households and individuals becomes all the more prominent. In short, this paper has sought to make a contribution to this aim and to outline the value in exploring the role of entrepreneurial competences further, though evidently more work remains to be done in this important area. 


\section{References}

Barbieri C. and Mshenga P. (2008) The role of firm and owner characteristics on the performance of agritourism farms. Sociologia Ruralis 48(2): 166-183.

Bergevoet R. H. M. (2005) Entrepreneurship of Dutch dairy farmers. Department of Social Sciences. Wageningen University.

Bergevoet R. H. M. and Van Woerkum C. (2006) Improving the Entrepreneurial Competencies of Dutch Dairy Farmers through the Use of Study Groups. The Journal of Agricultural Education and Extension 12(1): 25 - 39.

Bird B. (1995) Towards a theory of entrepreneurial competency. Advances in Entrepreneurship, Firm Emergence and growth 2: 51-72.

Bridge S., O'Neill K. and Martin F. (2009) Understanding Enterprise, Entrepreneurship and Small Business, Basingstoke: Palgrave Macmillan.

Brinckmann J. (2007) Competence of top management teams and success of new technologybased firms: a theoretical and empirical analysis concerning competencies of entrepreneurial teams and the development of their ventures, Wiesbaden: DUV.

Busby G. and Rendle S. (2000) The transition from tourism on farms to farm tourism. Tourism Management 21(6): 635-642.

Butts S., McGeorge A. and Briedenhann J. (2005) The Great Cornish Maize Maze. Culture and Agriculture 27(1): 61-68.

Chell E. (2008) The Entrepreneurial Personality: A Social Construction, London: Routledge.

Clark J. (2009) Entrepreneurship and diversification on English farms: Identifying business enterprise characteristics and change processes. Entrepreneurship \& Regional Development 21: 213-236.

Couzy C. and Dockes A.-C. (2008) Are farmers businesspeople? Highlighting transformations in the profession of farmers in France. International Journal of Entrepreneurial Behaviour and Research 6(3): 407-420.

Defra. (2007) Barriers to Farm Diversification: Report of the Joint Industry Working Group, London: Department for Environment, Food and Rural Affairs.

Defra. (2010) Impacts on Changes in the Wider Economy on Agriculture and the AgriEnvironment, London: Report prepared by The Andersons Centre, for Defra.

EU (2008) Other gainful activities: pluriactivity and farm diversification in EU-27, Brussels: European Union Directorate-General for Agriculture and Rural Development.

Eurostat. (2011) Eurostat Database (Other activities on the holding: Number of farms, agricultural area and economic size by legal status of holding, type of farming and economic size of farm). Available at: http://epp.eurostat.ec.europa.eu/.

Getz D., Carlsen J. and Morrison A. (2004) The family business in tourism and hospitality, Wallingford: CABI.

Hayton J. C. and McEvoy G. M. (2006) Guest editors' note. Human Resource Management 45(3): 291-294.

Hildenbrand B. and Hennon C. B. (2008) Beyond the concpet of 'getting big or getting out': entrepreneurship strategies to survive as a farm family. International Journal of Entrepreneurship and Small Business 6(3): 479-495.

Hill B. (2007) Business Competence, University of London: A report to Defra.

Hjalager a. (1996) Agricultural diversification into tourism Evidence of a European Community development programme. Tourism Management 17(2): 103-111.

Jones D., Moreddu C. and Kumagai T. (2009) The Role of Agriculture and Farm Household 
Diversification in the Rural Economy: Evidence and Initial Policy Implications, Paris: Organisation for Economic Co-operation and Development.

Kobia M. and Sikalieh D. (2010) Towards a search for the meaning of entrepreneurship. Journal of European Industrial Training 34(2): 110-127.

Koh K. and Hatten T. (2002) The Tourism Entrepreneur: The Overlooked Player In Tourism Development Studies. International Journal of Hospitality \& Tourism Administration 3(1): 21-48.

Lans T., Biemans H., Mulder M., et al. (2010) Self-Awareness of Mastery and Improvability in Small Business in the Agrifood Sector. Human Resource Development Quarterly 21(2): 147-168.

Lans T., Hulsink W., Baert H., et al. (2008) Entrepreneurship Education and Training in a Small Business Context: Insights from the Competence-Based Approach. Journal of Enterprising Culture 16(4): 363-383.

Lantra. (2005) Developing Business Competence: The Business Case for a Competence Framework, Coventry: Lantra (The Sector Skills Council for the Environmental and Land-Based Sector).

Lazear E. P. (2004) Balanced Skills and Entrepreneurship. American Economic Review 94(2): 208-211.

Lazear E. P. (2005) Entrepreneurship. Journal of Labor Economics 23(4): 649-680.

Le Deist F. D. and Winterton J. (2005) What is competence? Human Resource Development International 8(1): 27-46.

Li L. (2008) A review of entrepreneurship research published in the hospitality and tourism management journals. Tourism Management 29(5): 1013-1022.

Lichtenstein G. A. and Lyons T. S. (2001) The Entrepreneurial Development System: Transforming business talent and community economies. Economic Development Quarterly 15(3): 3-20.

Luken T. (2004) Zijn competenties meetbaar? [Are competencies measurable?]. Tijdschrift voor hoger onderwijs 22(1): 38-53.

Man T. W. Y. (2006) Exploring the behavioural patterns of entrepreneurial learning: A competency approach. Education + Training 48(5): 309-321.

Man T. W. Y., Lau T. and Chan K. F. (2002) The competitiveness of small and medium enterprises A conceptualization with focus on entrepreneurial competencies. Journal of Business Venturing 17(2): 123-142.

McElwee G. (2006) Farmers as Entrepreneurs: Developing Competitive Skills. Journal of Developmental Entrepreneurship 11(3): 187.

McElwee G. (2008) A taxonomy of entrepreneurial farmers. International Journal of Entrepreneurship and Small Business 6(3): 465-478.

McElwee G. and Bosworth G. (2010) Exploring the strategic skills of farmers accross a typology of farm diversification approaches. Journal of Farm Management 13(12): 819-838.

McGehee N. G. (2007) An Agritourism Systems Model: A Weberian Perspective. Journal of Sustainable Tourism 15(2): 111-124.

Meert H., van Huylenbroeck G., Vernimmen T., et al. (2005) Farm household survival strategies and diversification on marginal farms. Journal of Rural Studies 21(1): 81-97.

Mitchelmore S. and Rowley J. (2010) Entrepreneurial competencies: A literature review and development agenda. International Journal of Entrepreneurial Behaviour and Research 16(2): 92-111. 
Morgan S. L., Marsden T., Miele M., et al. (2010) Agricultural multifunctionality and farmers' entrepreneurial skills: A study of Tuscan and Welsh farmers. Journal of Rural Studies 26(2): 116-129.

Mulder M., Lans T., Verstegen J., et al. (2007) Competence development of entrepreneurs in innovative horticulture. Journal of Workplace Learning 19(1): 32-44.

NAO. (2004) Helping Farm Businesses in England, London: National Audit Office.

Nuthall P. L. (2006) Determining the important management skill competencies: The case of family farm business in New Zealand. Agricultural Systems 88(2-3): 429-450.

Nuthall P. L. (2010) Farm Business Management: The Human Factor, Wallingford: CABI.

Ollenburg C. (2008) Regional Signatures and Trends in the farm Tourism Sector. Tourism Recreation Research 33(1): 13-23.

People1st. (2007) Skill Needs Assessment for the hospitality, leisure, travel and tourism sector United Kingdom report, Uxbridge: People1st.

Phillipson J., Gorton M., Raley M., et al. (2004) Treating farms as firms? The evolution of farm business support from productionist to entrepreneurial models. Environment and Planning C: Government and Policy 22(1): 31-54.

Pyysiäinen J., Anderson A. R., McElwee G., et al. (2006) Developing the entrepreneurial skills of farmers: some myths explored. International Journal of Entrepreneurial Behaviour \& Research 12: 21-39.

Rae D. (2007) Entrepreneurship: from opportunity to action, Basingstoke: Palgrave Macmillan.

Schallenkamp K. and Smith W. L. (2008) Entrepreneurial skills assessment: the perspective of SBDC directors. International Journal of Management and Enterprise Development 5(1): $18-29$.

Sharpley R. and Vass A. (2006) Tourism, farming and diversification: An attitudinal study. Tourism Management 27(5): 1040-1052.

Silva O. (2007) The Jack-of-All-Trades entrepreneur: Innate talent or acquired skill? Economics Letters 97: 118-123.

Smit A. (2004) Changing external conditions require high levels of entrepreneurship in agriculture. Acta Horticulturae 655: 167-173.

Vesala H. T. and Vesala K. M. (2010) Entrepreneurs and producers: Identities of Finnish farmers in 2001 and 2006. Journal of Rural Studies 26: 21-30.

Vesala K. M. and Pyysiäinen J. (2008) Understanding Entrepreneurial Skills in the Farm Context, Frick, Switzerland: Research Institute of Organic Agriculture FiBL.

Wagner J. (2003) Testing Lazear's jack-of-all-trades view of entrepreneurship with German micro data. Applied Economics Letters 10(11): 687 - 689.

Wagner J. (2006) Are nascent entrepreneurs 'Jacks-of-all-trades'? A test of Lazear's theory of entrepreneurship with German data. Applied Economics 38(20): 2415 - 2419.

Wickham P. A. (2006) Strategic Entrepreneurship, Harlow: Pearson Education.

Wilson L.-A. (2007) The Family Farm Business? Insights into Family, Business and Ownership Dimensions of Open-Farms. Leisure Studies 26(3): 357-374.

Winterton J., Le Deist F. D. and Stringfellow E. (2006) Typology of knowledge, skills and competences: clarification of the concept and prototype, Luxembourg: The EU Centre for the Development of Vocational Training.

Wolf P. D., McElwee G. and Schoorlemmer H. (2007) The European farm entrepreneur: a comparative perspective. International Journal of Entrepreneurship and Small Business 4: 679-692. 